\title{
A Sustainable and Cost-effective Protocol for Cascade Oxidative Condensation of Furfural with Aliphatic Alcohols
}

Linhao Yu, ${ }^{\star}$ Shengyun Liao, ${ }^{*}{ }^{\dagger}$ Liangmin Ning, ${ }^{\star}$ Song Xue, ${ }^{\dagger}$ Zonghui Liu ${ }^{\dagger}{ }^{+}$Xinli Tong*+

†Tianjin Key Laboratory of Organic Solar Cells and Photochemical Conversion, School of Chemistry and Chemical Engineering, Tianjin University of Technology, No 391, Binshuixi Road, Tianjin 300384, P. R. China.

E-mail: tongxinli@tju.edu.cn (X. T.); mengyunliao@sina.com (S. L.)

Totals - 10 pages, 5 figures, and 6 tables

\section{Supporting Information}

Experimental.................................................... 2

Characterization of catalysts........................................... 3

Effect of reaction time and temperature ................................. 77

The control experiment for studying the catalytic mechanism................S8

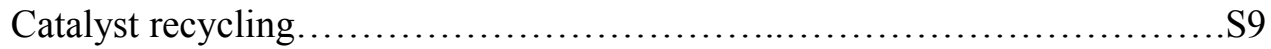




\section{Experimental}

\section{Reagents and instruments}

All chemicals and solvents are analytical grade and purchased from Aladdin reagent company (Shanghai, China), which are used without further purification.

X-ray powder diffraction (XRD) intensities were measured on a Rigaku D/max-IIIA diffractometer $(\mathrm{Cu}-\mathrm{K} \alpha, \lambda=1.54056 \AA)$. The powder samples were scanned from $10^{\circ}$ to $80^{\circ}$. IR spectra ( $\mathrm{KBr}$ pellets) were recorded on a Perkin-Elmer Spectrometer in the range 4000-400 $\mathrm{cm}^{-1}$. TGA experiments were performed in flowing $\mathrm{N}_{2}$ on a NETASCH TG 209F3 instrument with a heating rate of $10{ }^{\circ} \mathrm{C} / \mathrm{min}$ in the temperature range of $40-1000{ }^{\circ} \mathrm{C}$. BET surface areas, pore volumes, and average pore diameters of the prepared samples were obtained from $\mathrm{N}_{2}(77 \mathrm{~K})$ adsorption measurements by using a Micromeritics ASAP2020M system, in which the samples were pretreated under vacuum at $150{ }^{\circ} \mathrm{C}$ for $4 \mathrm{~h}$. The average pore diameters were calculated according to Barrett-Joyner-Halenda (BJH) model in adsorption and desorption period. The quantitative analyses of the products were determined on a GC apparatus with FID detector or on the Agilent 6890/5973 Gas Chromatograph-Mass Spectrometer (GC-MS) instrument.

The morphology of catalytic materials was obtained by scanning electron microscope (SEM: JSM-6301F, JEOL) equipped with a JED-2300 (JEOL) EDXS spectrometer for chemical analysis and transmission electron microscope (TEM: JEM-2100, JEOL).

\section{Synthesis of the supported $\mathrm{Co}_{\mathrm{x}} \mathrm{O}_{\mathrm{y}}-\mathrm{N}$ catalyst}

All the supported $\mathrm{Co}_{\mathrm{x}} \mathrm{O}_{\mathrm{y}}-\mathrm{N}$ catalysts are synthesized with a similar method reported in the reference [S1]. The preparation of $\mathrm{Co}_{\mathrm{x}} \mathrm{O}_{\mathrm{y}}-\mathrm{N} @ \mathrm{~K}-10$ is given as follows: $\mathrm{Co}(\mathrm{OAc})_{2} \cdot 4 \mathrm{H}_{2} \mathrm{O}(0.2490 \mathrm{~g}, 1.00 \mathrm{mmol})$ and 1,10-phenanthroline $(0.3964 \mathrm{~g}, 2.00$ mmol ) was dissolved in $15 \mathrm{~mL}$ ethanol and stirred at room temperature for $0.5 \mathrm{~h}$. Then K-10 (2.0000 g) was added and the reaction mixture was stirred at $60{ }^{\circ} \mathrm{C}$ for $4 \sim 5$ h. After the reaction mixture was cooled down to room temperature, ethanol was removed slowly under vacuum. The as-obtained solid was dried, ground to powder and pyrolyzed at $800{ }^{\circ} \mathrm{C}$ for $2 \mathrm{~h}$ in $\mathrm{N}_{2}$ atmosphere. The final powder was designated as $\mathrm{Co}_{\mathrm{x}} \mathrm{O}_{\mathrm{y}}-\mathrm{N} @ \mathrm{~K}-10$ catalyst and characterized by XRD, IR, TGA and BET.

The synthesis procedure of $\mathrm{Co}_{\mathrm{x}} \mathrm{O}_{\mathrm{y}} @ \mathrm{~K}-10$ is the same as the $\mathrm{Co}_{\mathrm{x}} \mathrm{O}_{\mathrm{y}}-\mathrm{N} @ \mathrm{~K}-10$ 
catalyst except for the absence of 1,10-phenanthroline.

\section{General procedure for the oxidative condensation of FUR with aliphatic alcohols}

All oxidative condensation experiments were performed in a $120 \mathrm{~mL}$ stainless steel autoclave equipped with the magnetic stirring and a temperature controller. Typical procedure for oxidation condensation of FUR with n-propanol is as follows: FUR (0.2000 g, 2 mmol), n-propanol (15 mL), the supported $\mathrm{Co}_{\mathrm{x}} \mathrm{O}_{\mathrm{y}}-\mathrm{N} @ \mathrm{~K}-10$ catalyst

$(0.0500 \mathrm{~g})$ and $\mathrm{Cs}_{2} \mathrm{CO}_{3}(0.0500 \mathrm{~g})$ were added into the autoclave. After the reactor was sealed, the pure oxygen was pumped to replace the atmosphere for several times. Then under the pressure of $0.3 \mathrm{MPa}$, the mixture was preheated to the set temperature with magnetic stirring and kept for a certain time. After the autoclave was cooled down and the excess gas was released, the as-obtained mixture was analyzed by GC and GC-MS.

\section{Characterization of catalysts}

\section{HRSEM and HRTEM images and EDXS detection}

The prepared Cobalt-based catalytic material is characterized by SEM and TEM technique (see Figure S1). For the SEM image, there are two kinds of regions: the bright region and the dark region. During the EDXS measurement, the content of Co is very high on the bright region; however, the content of Co is low and the content of $\mathrm{Si}$ is relatively high on the dark region (see Tables $\mathrm{S} 1$ ). But in the region with the dark particles, the content of Co is very low and the content of $\mathrm{Si}$ is high. So, it is concluded that the $\mathrm{Co}_{\mathrm{x}} \mathrm{O}_{\mathrm{y}}-\mathrm{N}$ particles should be contained on the bright region. The used support only exists on the dark region. The average weight contents for Co and $\mathrm{N}$ is $1.95 \mathrm{wt} \%$ and $2.94 \mathrm{wt} \%$. A small quantity of $\mathrm{Mg}$ element is originated from $\mathrm{K}-10$ support. 

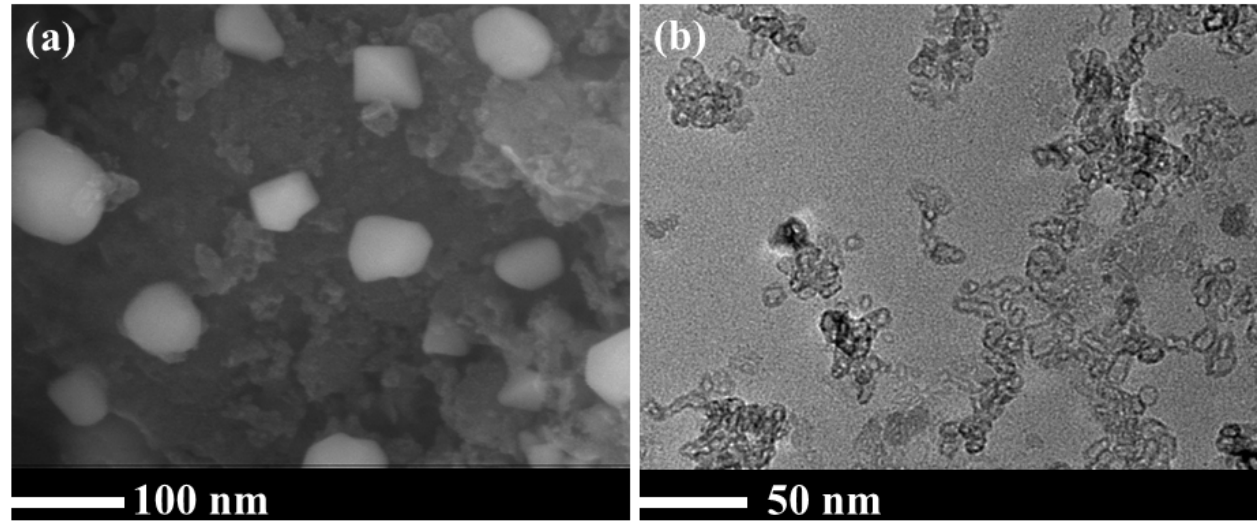

Figure S1. HRSEM images (a) and HRTEM images (b) of the supported $\mathrm{Co}_{\mathrm{x}} \mathrm{O}_{\mathrm{y}}-\mathrm{N}$ catalyst.

Table S1. The EDXS analysis of the supported $\mathrm{Co}_{\mathrm{x}} \mathrm{O}_{\mathrm{y}}-\mathrm{N} @ \mathrm{~K}-10$ catalyst.

\begin{tabular}{lllllll}
\hline Element & ${\text { Region } 1^{a}}^{a}$ & ${\text { Region } 2^{a}}^{a}$ & ${\text { Region } 3^{a}}$ & Region $4^{a}$ & Region $5^{a}$ & Region $6^{\text {a }}$ \\
\hline $\mathrm{C}$ & 28.84 & 17.92 & 47.21 & 25.11 & 19.95 & 23.78 \\
$\mathrm{~N}$ & 1.49 & 0.31 & 0.21 & 1.42 & 0.43 & 1.59 \\
$\mathrm{O}$ & 37.74 & 48.84 & 29.03 & 41.54 & 31.22 & 44.89 \\
$\mathrm{Mg}$ & 0.52 & 0.75 & 0.34 & 0.69 & 0.32 & 0.56 \\
$\mathrm{Al}$ & 4.41 & 3.97 & 2.98 & 3.64 & 2.85 & 3.57 \\
$\mathrm{Si}$ & 24.98 & 24.50 & 17.43 & 23.61 & 13.70 & 22.67 \\
$\mathrm{Co}$ & 2.02 & 3.71 & 2.80 & 3.99 & 31.53 & 2.94 \\
$\mathrm{C}$ & 28.84 & 17.92 & 47.21 & 25.11 & 19.95 & 23.78 \\
$\mathrm{~N}$ & 1.49 & 0.31 & 0.21 & 1.42 & 0.43 & 1.59 \\
\hline${ }^{a} \mathrm{All}$ & & & & & &
\end{tabular}

${ }^{a}$ All of the analyzed elements were normalized (Repeated for 3 times). The value of the element content is the weight percentage.

\section{XRD patterns}

Figure S2 shows the XRD patterns of the supported $\mathrm{Co}_{\mathrm{x}} \mathrm{O}_{\mathrm{y}}-\mathrm{N}$ or $\mathrm{Co}_{\mathrm{x}} \mathrm{O}_{\mathrm{y}}$ catalyst. All of samples show the characteristic peaks of $\mathrm{Co}, \mathrm{Co}_{2} \mathrm{O}_{3}$ and $\mathrm{Co}_{3} \mathrm{O}_{4}$, which is consistent with the report from Matthias Beller ${ }^{[\mathrm{S} 1]}$. For $\mathrm{Co}_{\mathrm{x}} \mathrm{O}_{\mathrm{y}}-\mathrm{N} @ \mathrm{~K}-10$, $\mathrm{Co}_{\mathrm{x}} \mathrm{O}_{\mathrm{y}} @ \mathrm{~K}-10, \mathrm{Co}_{\mathrm{x}} \mathrm{O}_{\mathrm{y}}-\mathrm{N} @$ Kaolin and $\mathrm{Co}_{\mathrm{x}} \mathrm{O}_{\mathrm{y}}-\mathrm{N} @ \mathrm{C}$ catalysts, no peaks of the supports were observed. However, the XRD patterns of $\mathrm{Co}_{\mathrm{x}} \mathrm{O}_{\mathrm{y}}-\mathrm{N} @ \mathrm{TiO}_{2}, \mathrm{Co}_{\mathrm{x}} \mathrm{O}_{\mathrm{y}}-\mathrm{N} @ \mathrm{SiO}_{2}$, $\mathrm{Co}_{\mathrm{x}} \mathrm{O}_{\mathrm{y}}-\mathrm{N} @ \mathrm{ZnO}$ and $\mathrm{Co}_{\mathrm{x}} \mathrm{O}_{\mathrm{y}}-\mathrm{N} @ \mathrm{Al}_{2} \mathrm{O}_{3}$ display the characteristic diffraction peaks of $\mathrm{TiO}_{2}, \mathrm{SiO}_{2}, \mathrm{ZnO}$ and $\mathrm{Al}_{2} \mathrm{O}_{3}$. 


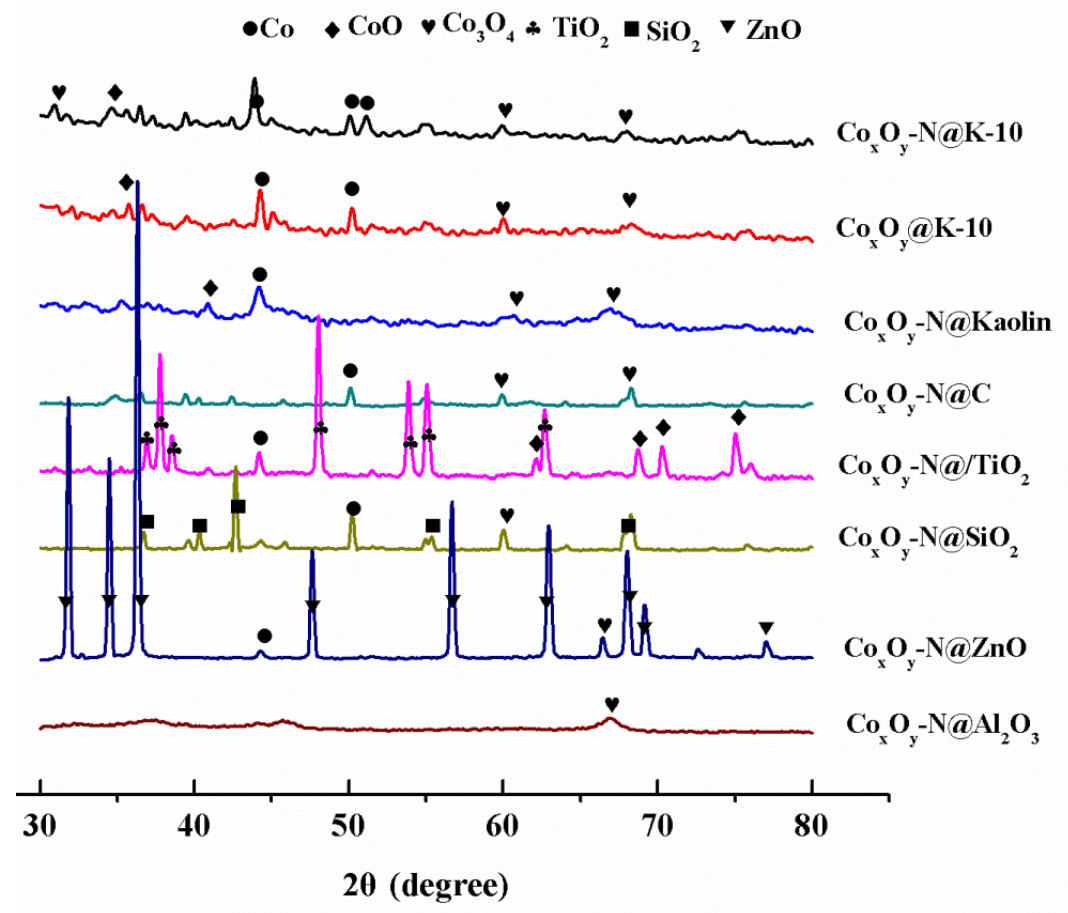

Figure S2. XRD patterns of different supported $\mathrm{Co}_{\mathrm{x}} \mathrm{O}_{\mathrm{y}}-\mathrm{N}$ catalysts.

\section{BET measurements}

Textural properties of the catalyst materials derived from the nitrogen physisorption are shown in Table S2. The BET surface area and pore volume of $\mathrm{Co}_{\mathrm{x}} \mathrm{O}_{\mathrm{y}}-\mathrm{N} @ \mathrm{~K}-10$ catalyst is larger than $\mathrm{Co}_{\mathrm{x}} \mathrm{O}_{\mathrm{y}} @ \mathrm{~K}-10, \quad \mathrm{Co}_{\mathrm{x}} \mathrm{O}_{\mathrm{y}}-\mathrm{N} @ \mathrm{ZnO}$, $\mathrm{Co}_{\mathrm{x}} \mathrm{O}_{\mathrm{y}}-\mathrm{N} @ \mathrm{TiO}_{2}, \mathrm{Co}_{\mathrm{x}} \mathrm{O}_{\mathrm{y}}-\mathrm{N} @ \mathrm{SiO}_{2}$. Furthermore, the average pore diameter of $\mathrm{Co}_{\mathrm{x}} \mathrm{O}_{\mathrm{y}}-\mathrm{N} @ \mathrm{~K}-10$ and $\mathrm{Co}_{\mathrm{x}} \mathrm{O}_{\mathrm{y}} @ \mathrm{~K}-10$ catalysts are larger than other catalysts. These data indicated the $\mathrm{Co}_{\mathrm{x}} \mathrm{O}_{\mathrm{y}}-\mathrm{N} @ \mathrm{~K}-10$ may display the higher catalytic performance, which was also verified by the experiments of catalytic oxidation condensation of FUR in FAO system.

Table S2. BET measurement of different supported $\mathrm{Co}_{\mathrm{x}} \mathrm{O}_{\mathrm{y}}-\mathrm{N} @ \mathrm{~K}-10$ or $\mathrm{Co}_{\mathrm{x}} \mathrm{O}_{\mathrm{y}} @ \mathrm{~K}-10$ catalysts.

\begin{tabular}{cccccc}
\hline \multirow{2}{*}{ Catalysts } & \multirow{2}{*}{$\begin{array}{c}\text { BET surface } \\
\text { area }\left(\mathrm{m}^{2} \mathrm{~g}^{-1}\right)\end{array}$} & $\begin{array}{c}\text { Pore volume }\left(\mathrm{cm}^{3} \mathrm{~g}^{-1}\right) \\
\text { adsorption }\end{array}$ & $\begin{array}{c}\mathrm{BJH} \\
\text { desorption }\end{array}$ & $\begin{array}{c}\text { Average pore diameter }(\mathrm{nm}) \\
\text { adsorption }\end{array}$ & $\begin{array}{c}\mathrm{BJH} \\
\text { desorption }\end{array}$ \\
\hline $\mathrm{Co}_{\mathrm{x}} \mathrm{O}_{\mathrm{y}}-\mathrm{N} @ \mathrm{~K}-10$ & 103.7164 & 0.142700 & 0.181484 & 5.7359 & 5.7663 \\
$\mathrm{Co}_{\mathrm{x}} \mathrm{O}_{\mathrm{y}} @ \mathrm{~K}-10$ & 43.9112 & 0.077243 & 0.109527 & 6.9579 & 7.2814 \\
$\mathrm{Co}_{\mathrm{x}} \mathrm{O}_{\mathrm{y}}-\mathrm{N} @ \mathrm{ZnO}$ & 45.1953 & 0.007020 & 0.007797 & 3.0689 & 4.1172 \\
$\mathrm{Co}_{\mathrm{x}} \mathrm{O}_{\mathrm{y}}-\mathrm{N} @ \mathrm{TiO}_{2}$ & 52.3006 & 0.010185 & 0.010903 & 3.3540 & 4.2640 \\
$\mathrm{Co}_{\mathrm{x}} \mathrm{O}_{\mathrm{y}}-\mathrm{N} @ \mathrm{SiO}_{2}$ & 29.9515 & 0.011624 & 0.012731 & 3.8961 & 3.7493 \\
\hline
\end{tabular}




\section{TG detection}

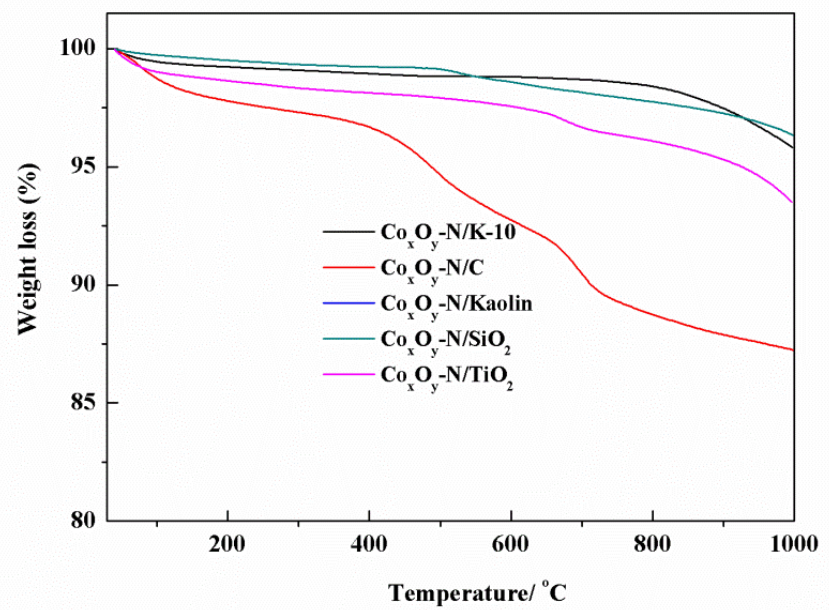

Figure S3. The TGA polts of the supported $\mathrm{Co}_{\mathrm{x}} \mathrm{O}_{\mathrm{y}}-\mathrm{N}$ catalysts.

To evaluate the thermal stability of the catalysts, TGA detection was performed on the used catalysts under $\mathrm{N}_{2}$ atmosphere with a heating rate of $10{ }^{\circ} \mathrm{C} / \mathrm{min}$, over the temperature range of $40-1000{ }^{\circ} \mathrm{C}$ (see Figure S3). In most cases, the weight loss during $400-800{ }^{\circ} \mathrm{C}$ should be attributed to the destruction of aromatic structure of molecular 1, 10-phenanthroline to release hydrogen or $\mathrm{C}_{\mathrm{m}} \mathrm{H}_{\mathrm{n}}$ gas. On the other hand, the weight loss of $\mathrm{Co}_{\mathrm{x}} \mathrm{O}_{\mathrm{y}}-\mathrm{N} @ \mathrm{C}$ is larger during $400-800{ }^{\circ} \mathrm{C}$ which can be due to the loss of active groups (such $-\mathrm{COOH}$ or hydroxyl group, etc.) on the active carbon.

\section{IR spectra}

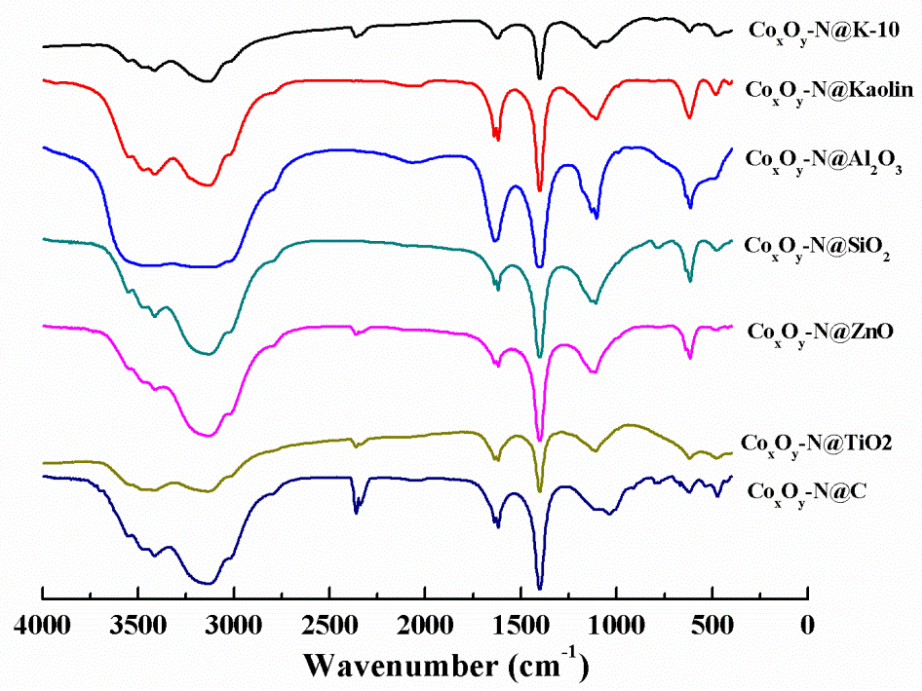

Figure S4. IR spectra of the supported $\mathrm{Co}_{\mathrm{x}} \mathrm{O}_{\mathrm{y}}-\mathrm{N}$ catalysts. 
The IR spectra of the supported $\mathrm{Co}_{\mathrm{x}} \mathrm{O}_{\mathrm{y}}-\mathrm{N}$ catalysts were recorded from the range of $400 \mathrm{~cm}^{-1} \sim 4000 \mathrm{~cm}^{-1}$ (Figure S4). The peak at $580 \mathrm{~cm}^{-1}$ may be ascribed to the characteristic of $\mathrm{Co}(\mathrm{III})$. The characteristic peaks of $\mathrm{Co}(\mathrm{II})$ at 740 and $830 \mathrm{~cm}^{-1}$ was also observed in all the samples. The peaks at 3401, 1410 and $1560 \mathrm{~cm}^{-1}$ should be attributed to the stretching vibration of $-\mathrm{OH}$.

\section{Effect of reaction time and temperature}

\section{The effect of temperature on the oxidative condensation of FUR with n-propanol}

As discussed in the paper, $\mathrm{Cs}_{2} \mathrm{CO}_{3}$ and $\mathrm{KOH}$ are the best additives. To optimize the reaction conditions, the effect of reaction temperature in both of $\mathrm{Co}_{\mathrm{x}} \mathrm{O}_{\mathrm{y}}-\mathrm{N} @ \mathrm{~K}-10+\mathrm{Cs}_{2} \mathrm{CO}_{3}$ and $\mathrm{Co}_{\mathrm{x}} \mathrm{O}_{\mathrm{y}}-\mathrm{N} @ \mathrm{~K}-10+\mathrm{KOH}$ systems were investigated and the results are summarized in Table S3. For these two systems, the optimal temperature was $140{ }^{\circ} \mathrm{C}$.

Table S3. Influences of reaction temperature on the catalytic oxidation condensation of FUR in FPO system

\begin{tabular}{|c|c|c|c|c|c|}
\hline \multirow{3}{*}{ Entry } & \multirow{3}{*}{$\mathrm{T}\left({ }^{\circ} \mathrm{C}\right)$} & \multicolumn{4}{|c|}{ Additive type } \\
\hline & & \multicolumn{2}{|c|}{$\mathrm{Cs}_{2} \mathrm{CO}_{3}$} & \multicolumn{2}{|c|}{$\mathrm{KOH}$} \\
\hline & & Conv. ${ }^{b}$ & Selec. for $\mathbf{2}^{c}$ & Conversion $^{b}$ & Selec. for $\mathbf{2}^{c}$ \\
\hline 1 & 160 & 75.3 & 93.5 & 82.2 & 92.6 \\
\hline 2 & 150 & 76.3 & 93.1 & 81.2 & 94.5 \\
\hline 3 & 140 & 75.1 & 92.8 & 82.3 & 93.2 \\
\hline 4 & 130 & 65.2 & 88.6 & 74.7 & 84.6 \\
\hline 5 & 120 & 45.1 & 88.9 & 71.1 & 80.1 \\
\hline 6 & 110 & 4.7 & 70.6 & 62.9 & 79.7 \\
\hline
\end{tabular}

\section{The effect of reaction time on oxidative condensation of FUR with n-propanol}

As shown in Table S4, we found the conversion of FUR and the selectivity of 2 increased with the reaction time increasing. When the reaction time was up $4 \mathrm{~h}$, a $75.1 \%$ conversion of FUR and $92.8 \%$ selectivity of 2 was obtained in the 
$\mathrm{Co}_{\mathrm{x}} \mathrm{O}_{\mathrm{y}}-\mathrm{N} @ \mathrm{~K}-10+\mathrm{Cs}_{2} \mathrm{CO}_{3}$ system. While in $\mathrm{Co}_{\mathrm{x}} \mathrm{O}_{\mathrm{y}}-\mathrm{N} @ \mathrm{~K}-10+\mathrm{KOH}$ system, the conversion and selectivity was up to $82.3 \%$ and $93.2 \%$, respectively. After reacting for $5 \mathrm{~h}$, the conversion and selectivity of 2 decreased slightly. So we concluded the optimal time for oxidation condensation of FUR in FPO system is $4 \mathrm{~h}$.

Table S4. Influences of reaction time on the catalytic oxidation condensation of FUR in FPO system.

\begin{tabular}{|c|c|c|c|c|c|}
\hline \multirow{3}{*}{ Entry } & \multirow{3}{*}{$\mathrm{T}(\mathrm{h})$} & \multicolumn{4}{|c|}{ Additive type } \\
\hline & & \multicolumn{2}{|l|}{$\mathrm{Cs}_{2} \mathrm{CO}_{3}$} & \multicolumn{2}{|l|}{$\mathrm{KOH}$} \\
\hline & & Conv. $^{b}$ & Selec. for $2^{b}$ & Conv. $^{b}$ & Selec. for $\mathbf{2}^{b}$ \\
\hline 1 & 1 & 31.1 & 73.1 & 53.7 & 61.2 \\
\hline 2 & 2 & 42.3 & 76.2 & 70.9 & 80.3 \\
\hline 3 & 3 & 64.8 & 88.1 & 79.1 & 88.1 \\
\hline 4 & 4 & 75.1 & 92.8 & 82.3 & 93.2 \\
\hline 5 & 5 & 73.3 & 87.5 & 80.1 & 93.1 \\
\hline
\end{tabular}

\section{The control experiment for studying the catalytic mechanism}

As shown in table $\mathrm{S} 5$, the $\mathrm{Co}_{\mathrm{x}} \mathrm{O}_{\mathrm{y}}-\mathrm{N} @ \mathrm{~K}-10+\mathrm{KOH}$ system shows the similar tendency with $\mathrm{Co}_{\mathrm{x}} \mathrm{O}_{\mathrm{y}}-\mathrm{N} @ \mathrm{~K}-10+\mathrm{Cs}_{2} \mathrm{CO}_{3}$.

Table S5. The results of control experiment for studying the catalytic reaction mechanism in $\mathrm{Co}_{\mathrm{x}} \mathrm{O}_{\mathrm{y}}-\mathrm{N} @ \mathrm{~K}-10+\mathrm{KOH}$ system. ${ }^{a}$

\begin{tabular}{ccccc}
\hline Entry & Reactant & Catalytic system & Conv. $(\%)^{b}$ & Product distribution (\%) $^{c}$ \\
\hline 1 & FUR+n-propanol & $\mathrm{Co}_{\mathrm{x}} \mathrm{O}_{\mathrm{y}}-\mathrm{N} @ \mathrm{~K}-10+\mathrm{KOH}$ & 82.3 & 93.2 for $\mathbf{2}$ \\
2 & FUR+propanal & $\mathrm{Co}_{\mathrm{x}} \mathrm{O}_{\mathrm{y}} \mathrm{-} \mathrm{N} @ \mathrm{~K}-10+\mathrm{KOH}$ & 73.2 & 91.1 for $\mathbf{2}$ \\
3 & FUR+propanal & $\mathrm{Co}_{\mathrm{x}} \mathrm{O}_{\mathrm{y}}-\mathrm{N} @ \mathrm{~K}-10$ & 4.2 & 97.6 for $\mathbf{3}$ \\
4 & FUR+propanal & $\mathrm{Cs}_{2} \mathrm{CO}_{3}$ & 87.6 & 94.1 for $\mathbf{2}$ \\
$5^{d}$ & FUR+n-propanol & $\mathrm{Co}_{\mathrm{x}} \mathrm{O}_{\mathrm{y}}-\mathrm{N} @ \mathrm{~K}-10+\mathrm{KOH}$ & 83.7 & 49.2 for $\mathbf{2}$ \\
$6^{f}$ & FUR+propanal & $\mathrm{Co}_{\mathrm{x}} \mathrm{O}_{\mathrm{y}}-\mathrm{N} @ \mathrm{~K}-10+\mathrm{KOH}$ & 98.5 & 96.4 for 2 \\
$7^{f}$ & FUR+n-propanol & $\mathrm{Co}_{\mathrm{x}} \mathrm{O}_{\mathrm{y}}-\mathrm{N} @ \mathrm{~K}-10+\mathrm{KOH}$ & 36.4 & 68.8 for acetal \\
\hline
\end{tabular}


${ }^{a}$ Reaction conditions: $0.2 \mathrm{~g}$ of $1,0.05 \mathrm{~g} \mathrm{Co}_{\mathrm{x}} \mathrm{O}_{\mathrm{y}}-\mathrm{N} @ \mathrm{~K}-10$ catalyst (2wt $\%$ loading) and $0.05 \mathrm{~g} \mathrm{KOH}$ in $15 \mathrm{~mL}$-propanol or propanal, under $0.3 \mathrm{MPa}$ of $\mathrm{O}_{2}$, at $140{ }^{\circ} \mathrm{C}$ for $4 \mathrm{~h} .{ }^{b}$ The conversion of substrate was obtained by the internal standard technique using GC. ${ }^{c}$ The selectivity of the product was acquired by the area normalization method in gas phase. ${ }^{d}$ The reaction was performed under a $\mathrm{N}_{2}$ atmosphere. ${ }^{f}$ The molar ratio of $\mathbf{1}$ with alcohol (aldehyde) is $10: 1$ (mol : mol); the value of conversion refers to that of alcohol (or aldehyde).

As shown in Table $\mathrm{S} 6, \mathrm{Cs}_{2} \mathrm{CO}_{3}$ and $\mathrm{KOH}$ can promote the hydrogen transfer process (Entries 2 and 3). While, the cobalt metal can further catalyze the reaction of furfuryl alcohol with $\mathrm{O}_{2}$ to furfural, which is useful to the condensation of furfural with propanal originated from Meerwein-Ponnserf-Verley process.

Table S6. The obtained data for detecting the hydrogen transfer process of FUR with n-propanol

\begin{tabular}{|c|c|c|c|c|c|}
\hline Entry & Reactant & Catalytic system & Conv. $(\%)^{b}$ & \multicolumn{2}{|c|}{ Product distribution $(\%)^{c}$} \\
\hline $1^{d}$ & FUR + n-propanol & $\mathrm{Co}_{\mathrm{x}} \mathrm{O}_{\mathrm{y}}-\mathrm{N} @ \mathrm{~K}-10$ & 21.51 & 18.3 for 3 & 81.7 for acetal \\
\hline $2^{d}$ & FUR+n-propanol & $\mathrm{Cs}_{2} \mathrm{CO}_{3}$ & 65.4 & 78.4 for $\mathrm{Y}^{e}$ & 21.6 for 2 \\
\hline $3^{d}$ & FUR+n-propanol & $\mathrm{KOH}$ & 76.8 & 65.8 for $\mathrm{Y}^{e}$ & 34.2 for 2 \\
\hline $4^{d}$ & FUR+n-propanol & $\mathrm{K}-10$ & 57.7 & 15.4 for 3 & 84.6 for acetal \\
\hline \multicolumn{6}{|c|}{$\begin{array}{l}{ }^{a} \text { Reaction conditions: } 0.2 \mathrm{~g} \text { of } 1,0.05 \mathrm{~g} \mathrm{Co}_{\mathrm{x}} \mathrm{O}_{\mathrm{y}} \mathrm{-N} @ \mathrm{~K}-10 \text { catalyst ( } 2 \mathrm{wt} \% \text { loading) or } 0.05 \mathrm{~g} \\
\text { additive or } 0.05 \mathrm{~g} \mathrm{~K}-10 \mathrm{in} 15 \mathrm{~mL} \text {-propanol at } 140{ }^{\circ} \mathrm{C} \text { for } 4 \mathrm{~h} .{ }^{b} \text { The conversion of substrate was } \\
\text { obtained by the internal standard technique using GC. }{ }^{c} \text { The selectivity of the product was } \\
\text { acquired by the area normalization method in gas phase. }{ }^{d} \text { The reaction was performed under } \mathrm{N}_{2} \\
\text { atmosphere. }{ }^{e} \mathrm{Y} \text { is furfural alcohol. }\end{array}$} \\
\hline
\end{tabular}

\section{Catalyst recycling}

The stability and recyclability of the catalyst is an important standard for measuring the performance of the catalysts. After the catalytic reaction, the catalyst was separated, and washed with anhydrous ethanol, and then dried at $80{ }^{\circ} \mathrm{C}$ for $12 \mathrm{~h}$ before being reused in the next run. Moreover, a new and equal amount of $\mathrm{Cs}_{2} \mathrm{CO}_{3}$ as the additive is added again in next run. 


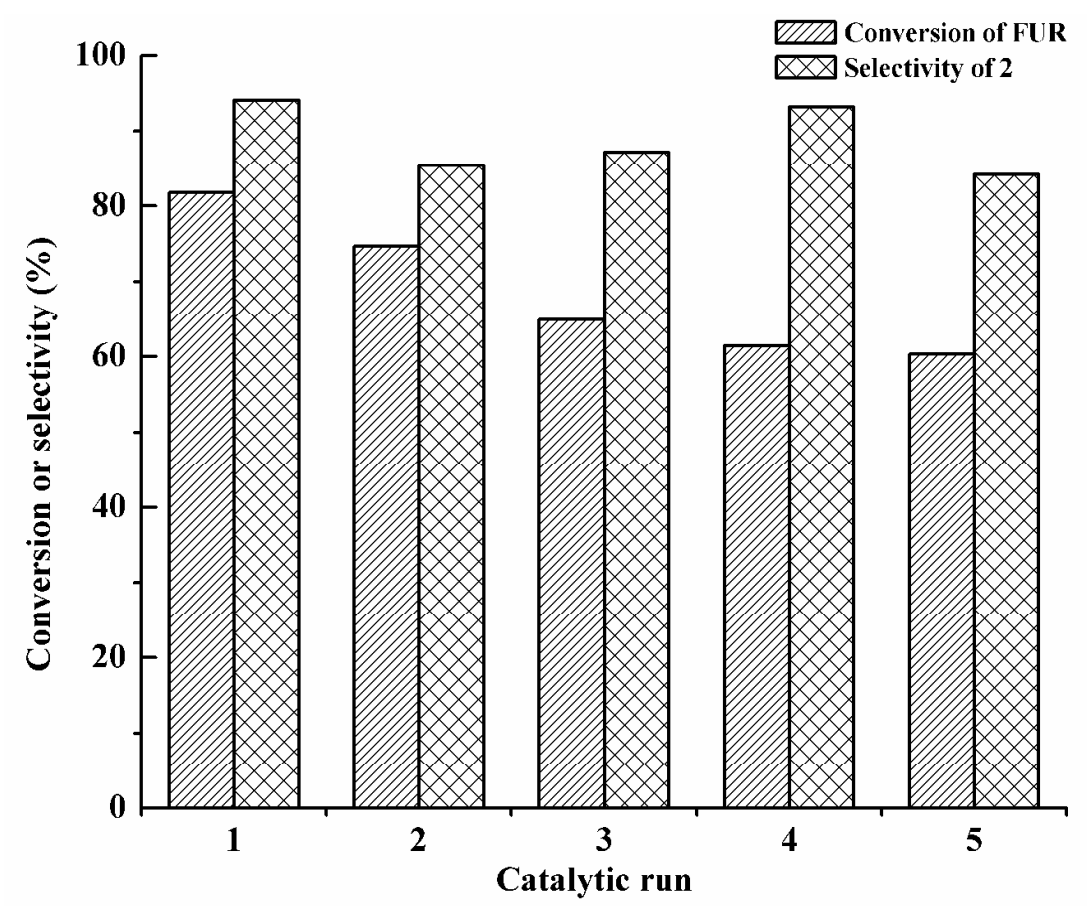

Figure S5. The recycling of the $\mathrm{Co}_{\mathrm{x}} \mathrm{O}_{\mathrm{y}}-\mathrm{N} @ \mathrm{~K}-10$ catalyst in the FPO system.

\section{References}

[S1] R. V. Jagadeesh, H. Junge, M. Pohl, J. Radnik, A. Brückner, M. Beller Selective Oxidation of Alcohols to Esters Using Heterogeneous $\mathrm{Co}_{3} \mathrm{O}_{4}-\mathrm{N} @ \mathrm{C}$ Catalysts under mild Conditions, J. Am. Chem. Soc. 2013, 135 (29), 10776-1078. 